\title{
Narracyjne uczenie się człowieka dorosłego Założenia teoretyczne
}

\begin{abstract}
Abstrakt
W tekście przedstawiono zarys teorii narracyjnego uczenia się opracowanej przez M. Carolyn Clark i Marshę Rossiter. Teoria oparta jest na założeniu, że ludzie rozumieją nie tylko siebie, ale także zmiany zachodzące w biegu ich życia w sposób narracyjny. Narracje są unikalnym sposobem nadawania znaczenia doświadczeniom życiowym. W ujęciu autorek narracyjne uczenie się stanowi ramę do rozważań w dwojakim sensie: 1) uczenie się poprzez historie (tj. słuchanie historii, opowiadanie historii i rozpoznawanie historii), 2) konceptualizacja uczenia się jako procesu narracyjnego.
\end{abstract}

Słowa kluczowe: narracja, narracja (auto)biograficzna, badania biograficzne, teoria narracyjnego uczenia się, narracyjne uczenie się.

\section{Theoretical Assumptions of Narrative Learning in Adulthood}

\begin{abstract}
The paper presents the main assumptions of the narrative learning theory developed by M. Carolyn Clark and Marsha Rossiter. The theory is based on the idea that people understand themselves as well as the changes over the course of their lives narratively. Narratives are a uniquely human way of giving meaning to life experience. According to the authors, narrative learning is a twofold concept: 1) learning through stories (listening to stories, telling stories, recognizing stories), 2) conceptualizing learning as a narrative process.
\end{abstract}

Keywords: narrative, (auto)biographical narrative, biographical research, narrative learning theory, narrative learning.

\footnotetext{
* Politechnika Wrocławska, Studium Nauk Humanistycznych i Społecznych.
} 
Wiele fenomenów społecznych i doświadczeń osobistych stanowiących przedmiot zainteresowania badaczy nauk społecznych wymyka się możliwościom ich badania w paradygmacie ilościowym. Odpowiedzi na pytania dotyczące tego, jak człowiek przeżywał różne wydarzenia życiowe (spodziewane, oczekiwane, ale także zaskakujące, trudne, dezorganizujące uporządkowany bieg życia), jak je rozumiał, interpretował, jak sobie $\mathrm{z}$ nimi radził, jak włączał w całość biografii, poszukiwane poprzez stosowanie zobiektywizowanych metod poznania są niepełne, deklaratywne, nieujmujące kontekstu i spektrum znaczeń nadawanych temu wydarzeniu przez doświadczający podmiot. Pożądane stają się tu badania dopuszczające do głosu osoby przeżywające, rozumiejące, interpretujące pewne wydarzenia życiowe - a więc badania oparte na narracji. Ich „celem nie jest poszukiwanie związków przyczynowo-skutkowych między faktami (...) a jest nim poznanie, opis i rozumienie subiektywnych światów życia człowieka" (Nowak-Dziemianowicz 2016: 36). Do tego rodzaju badań należy zakwalifikować badania biograficzne, które już mają swoją historię w polskiej andragogice (zob. Dubas 2011, 2014) i można obserwować systematyczny wzrost zainteresowania nimi rodzimych badaczy.

Badania biograficzne polegają na analizie historii życia człowieka opowiedzianej lub opisanej przez niego samego (autobiografia) lub kogoś innego (biografia). Głównym źródłem poznania jest tu narracja (auto)biograficzna. W literaturze przedmiotu narracje (auto)biograficzne są ujmowane jako zasób w procesie nauczania i uczenia się człowieka dorosłego, co znalazło zastosowanie m.in. w dydaktyce biograficznej (zob. Czerniawska 2007; Skibińska 2009). Proces uczenia się pozostający w związku z konstruowaniem narracji pomagają wyjaśnić rozwijane na gruncie andragogiki teorie: biograficznego uczenia się, transformatywnego uczenia się oraz narracyjnego uczenia się. W niniejszym tekście przedstawię założenia najsłabiej opisanej w polskiej literaturze przedmiotu teorii narracyjnego uczenia się autorstwa M. Carolyn Clark i Marshy Rossiter.

\section{Narracje (auto)biograficzne - pomiędzy (re)konstrukcją a (re)interpretacją historii życiowej}

Współcześnie w naukach humanistycznych i społecznych przyjmuje się, że „człowiek żyje w świecie opowieści i sam je tworzy. Wytwarzana przez niego wiedza jest wynikiem negocjacji między nim a światem, w którym żyje, i przyjmuje ona postać tekstu” (Jurgiel-Aleksander 2015: 81). Dlatego też coraz większego znaczenia nabiera pojęcie narracji. Autorzy stwierdzają, że „dojrzała osobowość jest narracją” (Dryll 2004: 9), „życie jest narracją” (Bruner 2004), „życie to historia tego życia poszukująca sposobu opowiedzenia o niej" (Ricouer 1992: 58), a opowiadanie możliwe jest dzięki tożsamości narracyjnej człowieka (tamże). Człowiek tworzy narracje w myślach, kiedy coś wspomina, planuje, próbuje zrozumieć, wytłumaczyć lub nadać sens pewnym wydarzeniom czy zachowaniom własnym bądź innych 
ludzi. Także komunikuje się z innymi poprzez snucie opowieści. Nic więc dziwnego, że narracje interesują badaczy, którzy za ich pośrednictwem próbują rozpoznać i wyjaśnić różnorodne fenomeny jednostkowe i społeczne.

W literaturze przedmiotu odnaleźć można wiele definicji pojęcia „narracja”. W książce Narrative Knowing and the Human Sciences (1988) Donald E. Polkinghorne stwierdza, że termin „narracja” można odnieść do „procesu tworzenia opowieści, (...), lub do rezultatu tego procesu - nazywanego także opowieściami, opowiadaniami lub historiami" (Polkinghorne 1988: 13). W tej definicji narracja nie jest rozumiana wyłącznie jako wytwór, produkt opowiadania, ale także jako sam proces konstruowania opowieści. I taka perspektywa jest przyjmowana przez wielu współczesnych badaczy. Kate de Medeiros stwierdza, że narracja jest „oralnym lub pisemnym opowiadaniem o wybranych aspektach samego siebie poprzez temporalnie uporządkowane wydarzenia zjednoczone wspólnym, głównym wątkiem” (de Medeiros 2014: 11). Przedstawiane wydarzenia są „wybrane, zorganizowane, połączone ze sobą i spostrzegane jako znaczące dla określonej publiczności" (Riessman 2008: 3). Narracja wymaga zatem działań komunikacyjnych zarówno od jej autora (mówiącego lub piszącego), jak i odbiorcy (słuchacza lub czytelnika). Autor narracji tworzy ją z pewną intencją, zamiarem. Jak stwierdza Gay Becker, narracje odzwierciedlają doświadczenia ludzi w taki sposób, jak oni (tj. autorzy narracji) je widzą i jak chcieliby, żeby postrzegali je inni (Becker 1997: 25). Natomiast nigdy nie ma pewności, jak narracje zostaną zrozumiane przez innych. Tworzenie narracji i jej odbieranie jest bowiem „konstruktywnym procesem ugruntowanym w specyficznych uwarunkowaniach kulturowych, interakcji i historii. Tekst, kontekst i znaczenie są ze sobą powiązane" (Garro, Mattingly 2000: 22). W sposób szczególny uwzględniają to Luk van Langenhove i Rom Hareé, definiując narracje jako „rezultat interakcji pomiędzy narratorem, widownią i pamięcią narratora" (van Langenhove, Hareé 1993: 87). Narracje zawsze - bez względu na ich formę - są tworzone dla pewnej widowni i z myślą o niej. W przypadku narracji ustnych odbiorca jest obecny, a więc może przerywać, zadawać pytania, zachęcać do opowiadania bądź utrudniać je, a więc odbiorca wpływa na ostateczną zawartość i treść narracji. Narracje pisemne są chronione przed interwencjami odbiorcy, widownia jest milcząca, pozostaje jedynie w wyobraźni narratora (tamże: 90).

Jak stwierdza K. de Medeiros, „nie ma jednej właściwej drogi myślenia o narracjach. Zamiast niej, jest wiele możliwości" (de Medeiros 2014: 6). Pomocna zatem w uporządkowaniu różnych stanowisk wobec narracji może być klasyfikacja Elżbiety Dryll (2004: 9-12), w której autorka wyróżniła trzy podejścia do narracji:

1) narracja jako ,jednostkowy tekst”,

2) narracja jako „tekst osoby”,

3) narracja jako „tekst kultury”.

W pierwszym ujęciu narracja pojmowana jest jako konkretna realizacja językowa, czyli „opowiadanie komuś czegoś w określonym czasie i okolicznościach” 
(Dryll 2004: 9). Może występować w formie pisemnej i ustnej. Jest nią zarówno narracja „wielka” (narracja uznana i rozpoznawana w danej kulturze, np. znaczące dzieło literackie), narracja „średniego zasięgu” (ważne opowiadanie, ale nie ponadczasowe; o różnej wartości artystycznej i sile oddziaływania, np. film, teksty prasowe), jak i „mała” (codzienne opowieści tworzone przez ludzi w ramach zachodzących interakcji społecznych) (zob. Dryll 2014).

W drugim znaczeniu, narracja rozumiana jest jako „sposób porządkowania znaczeń w umyśle człowieka” (Dryll 2004: 9). System znaczeń człowieka jest złożonym schematem poznawczym, który „organizuje napływające informacje (...) oraz kontroluje ich wykorzystywanie w procesie działania, zarówno w warstwie językowej (w mowie), jak i behawioralnej (w czynie)" (tamże: 10). Psychologowie narracyjni przyjmują, iż narracja pozwala strukturyzować doświadczenie oraz organizować posiadaną i zdobywaną wiedzę (w szczególności dotyczącą siebie i świata społecznego), a tym samym lepiej rozumieć siebie i swoje działanie, innych ludzi, relacje społeczne i otaczającą rzeczywistość. Kolejne wydarzenia życiowe uruchamiają nowe narracje i mogą prowadzić do modyfikowania treści dotychczasowych. Człowiek może tworzyć narracje przybierające formę wyartykułowanych ustnie lub pisemnie komunikatów. Proces narracyjny może oznaczać także poznawcze organizowanie napływających danych przyjmujące postać dialogu wewnętrznego, rozmowy z samym sobą, tłumaczenia samemu sobie tego, co się wydarzyło. W jednym i drugim wypadku uruchamiane są tzw. schematy narracyjne „odpowiedzialne za tworzenie opisów rzeczywistości w postaci historii, opowieści, narracji” (Nowak-Dziemianowicz 2016: 33). Schematy narracyjne składają się z następujących komponentów: bohaterowie (aktorzy) wydarzeń; ich wartości, intencje i plany realizacji; możliwe komplikacje w realizacji owych intencji; uwarunkowania i szanse przezwyciężenia trudności i realizacji planów (Trzebiński 2001: 95). Ustrukturyzowanie doświadczeń w narracje pomaga radzić sobie z rozmaitymi wydarzeniami życiowymi, w szczególności z wydarzeniami trudnymi i nieplanowanymi.

Trzecie podejście wobec narracji ujmuje ją jako „tekst kultury” i w tym rozumieniu narracja staje się obiektywnym elementem kultury, nasyconym symbolami i wartościami, niemającym swojego właściciela, a jednocześnie niezależnym od poznającego człowieka. Przykładem mogą być przekazywane z pokolenia na pokolenie mity i baśnie, wierzenia ludowe. Człowiek poznaje zawarte w tekście kultury treści i przyswaja obecny w nim system znaczeń. Dzieje się to przede wszystkim w toku komunikacji interpersonalnej będącej atrybutem procesu wychowania, socjalizacji, edukacji i innych procesów społecznych. Poznawanie tekstów kultury wpływa na wszechstronny rozwój człowieka, w tym także na jego kompetencje narracyjne niezbędne do tworzenia własnych narracji, nazwanych przez E. Dryll tekstami osoby. Opowiadając historie swojego życia, człowiek nawiązuje do treści zawartych w tekstach kultury, czerpie z wiedzy społecznej, a to 
powoduje, że opowiadane przez niego „historie nigdy nie są całkowicie subiektywne" (Tedder, Biesta 2009: 24).

Narracja (auto)biograficzna, stanowiąca przedmiot zainteresowania badaczy biografii, jest zatem „tekstem osoby”. Stanowi ona opowieść o (własnym) życiu lub jego fragmencie, jest próbą rekonstrukcji tego, co się wydarzyło, z pewnej perspektywy czasowej. Rekonstrukcji towarzyszy (re)interpretacja. W autobiografii człowiek transformuje swoje życie w opowieść (Karpiak 2000: 34). Jej autor wybiera te wydarzenia życiowe, które uznaje za warte przywołania i opowiedzenia. Układa je na osi czasu, samodzielnie decydując, co będzie początkiem, a co zakończeniem opowiadanej historii życia. Narrację (auto)biograficzną wypełniają nie tylko opisy zdarzeń, ale także miejsc, osób, okoliczności składających się na pewien kontekst sytuacji itd. Zawierają także osobistą interpretację i znaczenie nadawane minionym wydarzeniom oraz zachowaniom, działaniom własnym i innych bohaterów opowieści. Narrator tworzy światy wewnętrzne osób uczestniczących we wspominanych doświadczeniach (zob. Maruszewski 2005). Dzięki temu narracja staje się drogą do wyjaśnienia i rozumienia rzeczywistości, rozumienia siebie i biegu własnej biografii (poprzez m.in. poszukiwanie związków przyczynowo-skutkowych) oraz postępowania innych ludzi. W tym kontekście ujawnia się jej edukacyjny i terapeutyczny potencjał.

Narrator tworzy fabułę, w której przedstawia minione wydarzenia oraz działania, podejmowane przez uczestników tych wydarzeń - aktorów odgrywających pewne role. W swej opowieści sam staje się aktorem. Aktorzy i wydarzenia są osadzone w pewnym kontekście (czas, miejsce, kultura itd.). W narracji nie opisuje wszystkich epizodów życiowych, ale selekcjonuje je, wybiera te, które z jakiegoś powodu są warte opowiedzenia, nadaje im pewne znaczenia, łączy ze sobą, organizuje w pewną powiązaną ze sobą całość, inne pomija bądź po prostu przemilcza. Jednocześnie interpretuje, próbuje zrozumieć, wyjaśnić, czasem ocenia zachowanie i postawy aktorów biorących udział w tych wydarzeniach. Czasem celowo bądź nieświadomie nie odzwierciedla rzeczywistości, którą zapamiętał, ale ją zmienia, stawia siebie w lepszym bądź gorszym świetle. Dlatego trudno jest badaczowi oddzielić fikcję od rzeczywistości, kreację od autentyczności (zob. Mazurek 2015). „Narracja nie jest przypadkową serią słów bez znaczenia” (de Medeiros 2014: 2), lecz sposobem na uporządkowanie, zrozumienie, wyjaśnienie doświadczeń życiowych z pewnej perspektywy czasu, poszukanie wzajemnych związków pomiędzy nimi, a także na wypracowanie wizji dalszego biegu życia i własnej osoby.

Warto także odnotować, że narracje nie stanowią lustrzanego odbicia rzeczywistości i przeszłości, zawierają w sobie ich wspomnienie i osobistą interpretację. Nawet trudno byłoby „(...) sobie wyobrazić pełną i chronologiczną zgodność między przeżytym życiem a opowiadaniem o nim. Opowiadanie nie tyle odbija życie w całej jego pełni, ale raczej je rekonstruuje z jakiejś perspektywy" (Urbaniak-Zając 2011: 22). Ponadto „narracja jest aktem nadawania sensu” (Clark 2010: 3). 
Zdaniem Catherine Kohler Riessman sam fakt, że opowiadający bardziej interpretuje przeszłość aniżeli reprodukuje ją, wpływa na użyteczność narracji w badaniach naukowych (Riessman 2005: 6). Dzięki temu możliwe jest nie tylko odtworzenie pewnej historii, ale poznanie, jak uczestnicy, świadkowie pewnych wydarzeń je zapamiętali, jakie nadają im znaczenia i jak je oceniają. Co więcej, istota, ale także i wartość narracji polega na tym, że pozostają one pod wpływem kontekstu wyznaczanego przez biografię człowieka. Te same wydarzenia narrator może opowiedzieć w różny sposób na różnych etapach swojego życia czy też w różnych okolicznościach. Przyczyn takiej sytuacji może być wiele. Jedną z nich jest upływający czas (zob. Dubas 2014), poznawanie konsekwencji zaistniałych wydarzeń i podejmowanych działań, a także gromadzenie kolejnych doświadczeń życiowych, które mogą zmienić perspektywę i sposób patrzenia na to, co już minęło. Innymi przyczynami tego, że człowiek opowiada tę samą historię życia w odmienny niż wcześniej sposób są m.in. różnorodne zniekształcenia pamięci (np. zniekształcenia służące ego, luki w pamięci faktograficznej), „procesy poszukiwania i nadawania sensu pamiętanym zdarzeniom" (Maruszewski 2005: 26) stanowiące główne źródło zniekształceń pamięci autobiograficznej (tamże), system językowy, którym dysponuje narrator (zob. Dryll, Cierpka 2011), uwarunkowania społeczno-kulturowe, wreszcie podejmowanie decyzji przez narratora, jak przedstawić przeszłość i siebie w przeszłości z perspektywy teraźniejszości, w momencie opowiadania (Bruner 1990). To powoduje, że narracja autobiograficzna to nie tylko konstruowanie danej wersji swojego życia, ale konstruowanie danej wersji samego siebie (Tedder, Biesta 2009: 21).

Narracje zawsze są osadzone w jakimś kontekście kulturowym (zob. też Nowak-Dziemianowicz 2014). Kultura wpływa na to, co mówimy, w jaki sposób, komu, w jakich okolicznościach. Jak już wcześniej wspomniałam, dzięki zasobom kultury narracje są w ogóle możliwe. Poprzez wychowanie i uczenie się przygotowujemy się do odczytywania „wielkich” narracji i tworzenia własnych „małych” narracji. Żyjąc wśród ludzi, przysłuchujemy się pewnym historiom, opowiadamy własne, nadajemy znaczenia i interpretujemy wydarzenia w wyniku międzyludzkich negocjacji (Trzebiński 2001). Dlatego zdarza się, że członkowie pewnych grup społecznych opowiadają nie tyle o swoim życiu i osobistym spojrzeniu na pewne wydarzenia w ich biografii, ale posługują się językiem przyjętym w tych grupach i wyjaśniają doświadczenia tak, jak inni członkowie grupy. W tym kontekście można mówić o społecznym konstruowaniu znaczeń poprzez narracje. „Narracje są kształtowane przez oczekiwania i zasady obowiązujące w danej kulturze" (de Medeiros 2014: 8) i grupie społecznej. W niektórych grupach może brakować „kulturowej autoryzacji” (Couser 1997: 12) na mówienie o pewnych sprawach (tzw. tematy tabu) lub w inny sposób niż zostało to przyjęte przez grupę. 


\section{Narracyjne uczenie się - zarys teorii}

Teoria narracyjnego uczenia się opracowana przez M. C. Clark i M. Rossiter odwołuje się do spostrzegania człowieka jako homo narrans, a więc istoty zdolnej do opowiadania. W tym kontekście opowiadanie należy traktować jako działanie niezbędne dla kształtowania się tożsamości i rozwoju. Autorki przyjmują, że człowiek nadaje sens każdemu doświadczeniu poprzez „konstruowanie go w jakiś rodzaj opowieści” (Clark 2010: 3). A skoro „nadajemy sens naszemu doświadczeniu poprzez opowiadanie, to znaczy, że konstruujemy rozumienie siebie w sposób narracyjny" (tamże: 4). W taki sposób rozumiemy także zmiany następujące w biegu życia (Clark, Rossiter 2008: 62). Wyzwalają one konieczność zmiany narracji autobiograficznej. Konstrukcja akceptowalnej opowieści o życiu jest centralnym procesem w rozwoju człowieka dorosłego (tamże). Budowanie narracji nie jest jednak procesem wyłącznie osobistym, lecz zanurzonym w rozmaitych kontekstach społecznych i kulturowych (Rossiter 2002; Clark, Rossiter 2008; Clark 2010). Człowiek żyje i rozwija się w „świecie nasyconym narracjami” (ang. narrative-saturated world) (Clark 2010: 4), które pomagają mu poznawać, rozumieć i wyjaśniać otaczającą go rzeczywistość, a jednocześnie interpretować doświadczenia własne i innych ludzi. Tworzy zatem osobiste narracje w oparciu o dostępne w kulturze i społeczeństwie opowieści.

Ważną kategorią w wyjaśnianiu procesu narracyjnego uczenia się jest doświadczenie życiowe (Clark, Rossiter 2008). Dostrzeganie związku pomiędzy doświadczeniem a uczeniem się nie jest nowe w teorii edukacji dorosłych, można wręcz stwierdzić, iż jest to jedno z fundamentalnych założeń andragogiki (zob. Knowles 1980). Aczkolwiek istnieją różnice w sposobie wyjaśniania związku pomiędzy doświadczeniem a uczeniem się dorosłego w poszczególnych teoriach (np. transformatywnego uczenia się, uczenia się z doświadczenia, uczenia się usytuowanego, biograficznego uczenia się, narracyjnego uczenia się) (zob. Golonka-Legut 2012; Mazurek 2017). W teorii narracyjnego uczenia się zakłada się, że doświadczenie pojawia się niezależnie od języka. Natomiast człowiek ma do niego dostęp, zastanawia się nad nim, nadaje mu sens poprzez narrację (Clark 2010: 5). Doświadczenie jest nazywane, opisywane już po fakcie, a proces tworzenia narracji jest nadawaniem znaczenia doświadczeniu przez uczącego się (Clark, Rossiter 2008: 64).

Narracyjne uczenie się w ujęciu M. C. Clark i M. Rossiter (2008: 64-67) stanowi ramę teoretyczną, którą można wykorzystać dwojako: 1) do wyjaśnienia procesu uczenia się poprzez opowieści (ang. learning through stories); 2) do konceptualizacji uczenia się jako procesu narracyjnego (ang. learning as a narrative process).

Po pierwsze, narracyjne uczenie się jest to uczenie się poprzez słuchanie historii, opowiadanie historii i rozpoznawanie historii. Słuchanie historii polega nie tylko na ich odbieraniu, ale także interpretacji, czyli nadawaniu znaczenia przez słuchającego-uczącego się. Opowieści angażują słuchającego nie tylko poprzez sferę 
poznawczą, ale także duchową, emocjonalną, uruchamiają jego wyobraźnię itd. Przywołują wspomnienia przeżytych już własnych doświadczeń, które stają się ponownie urzeczywistnione. Samodzielne opowiadanie historii z kolei powoduje, że uczący się staje się autorem opowieści pełniącym w niej rolę aktora. Tym samym wzrasta jego zaangażowanie. Narracja jest tutaj pomostem pomiędzy doświadczeniem a uczeniem się, bez niej nie byłoby możliwe uczenie się. Trzeci sposób narracyjnego uczenia się polega na rozpoznawaniu narracji, w jakich jesteśmy umieszczeni. Rozpoznawanie opowieści zakłada, że uczący się zaczyna rozumieć narracyjny charakter doświadczenia i dostrzega, że jego sposób myślenia jest ukształtowany poprzez wpływy społeczno-kulturowe (a więc różne narracje). Konsekwencją może być krytyczne ustosunkowanie się do owych wpływów. Przykładowo, dzięki zetknięciu się z narracjami przyjętymi w innym kręgu kulturowym człowiek może spostrzec, jak jego tożsamość została ukonstytuowana narracyjnie, ale także może wybrać inny sposób myślenia (tj. inną narrację) o pewnej rzeczywistości. Słuchanie, opowiadanie i rozpoznawanie historii są trzema możliwymi drogami narracyjnego uczenia się.

Po drugie, teoria narracyjnego uczenia się oferuje także „nowy sposób myślenia o tym, jak przebiega proces uczenia się" (Clark, Rossiter 2008: 66). Jak przekonują autorki koncepcji, istota uczenia się polega na nadawaniu poznawanym treściom sensu, dostrzeganiu wewnętrznej spójności i logiki w poznawanej wiedzy oraz sprawdzaniu, jaki jest związek pomiędzy wiedzą nową a już przyswojoną. W jaki sposób robi to uczący się? Poprzez tworzenie narracji o tym, czego się uczy. Może ją tworzyć wyłącznie w myślach, ale także mówiąc, pisząc; samodzielnie lub w grupie. Narracja jest potrzebna, żeby połączyć ze sobą pewne segmenty wiedzy. Proces konstruowania narracji polega na opisywaniu własnego rozumienia czegoś, nadawaniu poznawanym treściom sensu. W ramach tego procesu uczący się identyfikuje treści, których nie może do siebie dopasować (tj. treści niezrozumiałe) i dostrzega luki w wiedzy (tj. braki w wiedzy). W miarę wykonywania pracy nad narracją, staje się ona sensowna i koherentna. Uczenie się polega zatem na konstruowaniu narracji, „ubieraniu” w słowa poznawanych i rozumianych treści. Nauczanie kogoś z kolei powoduje często konieczność zmiany dotychczasowej narracji, opowiedzenia czegoś w inny sposób, za pomocą innych, bardziej zrozumiałych dla drugiej osoby słów. I to, zdaniem M. C. Clark i M. Rossiter, pogłębia wiedzę nauczającego (a jednocześnie uczącego się) w pewnym zakresie.

\section{Podsumowanie}

Ludzie są istotami zdolnymi do tworzenia opowieści, poprzez które nadają znaczenie nabywanym w ciągu życia doświadczeniom. Nadawanie znaczenia jest procesem narracyjnym (Polkinghorne 1988; Bruner 1990; Frank 1995; Trzebiński 2001; Rosenthal 2003; Clark, Rossiter 2008). „Narracja jest (...) sposobem rozumienia 
działań własnych oraz podejmowanych przez inne osoby, sposobem organizowania zdarzeń i obiektów w znaczącą całość oraz łączenia ze sobą oraz przyglądania się konsekwencjom działań i zdarzeń na przestrzeni czasu" (Nowak-Dziemianowicz 2014: 12). Narracje są mostem łączącym przeszłość z teraźniejszością i przyszłością. Jak stwierdza Arthur Frank: „Historie są sposobem na odnowienie, zrekonstruowanie wyznaczonych dotychczas map oraz znalezienie nowych wyzwań" (Frank 1995: 53). Umożliwiają zrozumienie tego, co trudno było dotychczas wyjaśnić i zinterpretować.

Opowiadanie historii swojego życia czy też opowiadanie o pewnych wydarzeniach trudnych może przynieść ulgę narratorowi, pomóc mu zrozumieć minione wydarzenia i wypracować skuteczne mechanizmy radzenia sobie. Podczas aktu narracji to, co dotąd obce, nieznane, przemilczane, tabuizowane, zostaje przekształcone w znane i oswojone (Rosenthal 2003: 924). „Oznacza to, że narracja jest jednym z możliwych sposobów uczenia się z życia” (Tedder, Biesta 2009: 23). Opowieści umożliwiają narracyjne uczenie się, którego istotą jest nadawanie znaczenia doświadczeniom życiowym. W tym rozumieniu uczenia się wyraża się także terapeutyczny wymiar narracji autobiograficznych, określany jako „psychiczna odbudowa” (Hawkins 1999), „efekt ukojenia” (Rosenthal 2003), oczyszczenie podobne do uzyskiwanego dzięki spowiedzi (Tembeck 2009).

Zdarza się jednak, że narracje autobiograficzne stają się „miejscem uwięzienia” jednostki i nie pomagają jej „ruszyć dalej” (Tedder, Biesta 2009: 23), blokując zarówno proces uczenia się, jak i działania. To „uwięzienie” wyraża się w braku lub znikomej elastyczności skonstruowanej historii, trudności w znalezieniu alternatywnych sposobów opisania siebie i swojego życia, a tym samym w wypracowaniu alternatywnych możliwości działania (tamże). „Wybór narracji - sens, jaki nadajemy doświadczeniu - determinuje to, jak odpowiadamy na to doświadczenie i jak z nim sobie radzimy" (Clark, Rossiter 2008: 62).

\section{Bibliografia}

Becker G. (1997) Disrupted Lives: How People Create Meaning in a Chaotic World, Berkeley and Los Angeles, University of California Press.

Bruner J. (1990) Acts of meaning, London, Harvard University Press.

Bruner J. (2004) Life as Narrative, „Social Research”, vol. 71, no 3, s. 691-710.

Clark C. M. (2010) Narrative Learning: Its Contours and Its Possibilities, "New Directions For Adult \& Continuing Education", no 126, Special Issue "Narrative Perspectives on Adult Education", s. 3-11.

Clark C. M., Rossiter M. (2008) Narrative Learning in Adulthood, "New Directions for Adult \& Continuing Education", no 119, s. 61-70. 
Couser G. T. (1997) Recovering Bodies. Illness, Disability, and Life Writing, Madison, The University of Wisconsin Press.

Czerniawska 0. (2004) Od badań biograficznych do dydaktyki biograficznej, „Edukacja Dorosłych", nr 3.

de Medeiros K. (2014) Narrative Gerontology in Research and Practice, New York, Springer Publishing Company.

Dryll E. (2004) Homo narrans - wprowadzenie w: Narracja. Koncepcje i badania psychologiczne, E. Dryll, A. Cierpka (red.), Warszawa, Wydawnictwo Instytutu Psychologii PAN, s. 7-20.

Dryll E. (2014) Narracje rodzinne w: Psychologia rodziny, I Janicka, H. Liberska (red.), Warszawa, Wydawnictwo Naukowe PWN, s. 76-93.

Dryll E., Cierpka A. (2011) Zagadnienia teoretyczne nurtujące polska psychologię narracyjnq. Wprowadzenie w: Psychologia narracyjna. Tożsamość, dialogowość, pogranicza, E. Dryll, A. Cierpka (red.), Warszawa, Wydawnictwo Eneteia.

Dubas E. (2011) „Uczenie się z (własnej) biografii” - wprowadzenie w: Biografia i badanie biografii, t. 1, Uczenie się z (własnej) biografii, E. Dubas, W. Świtalski (red.), Łódź, Wydawnictwo Uniwersytetu Łódzkiego, s. 5-9.

Dubas E. (2014) Czas, biografia i badania biograficzne - różnorodność kontekstów w andragogicznej perspektywie, Edukacja Dorosłych, Nr 2 (71), s. 13-27.

Frank A. W. (1995) The wounded storyteller. Body, illness, and ethics, Chicago-London, The University of Chicago Press.

Garro L., Mattingly Ch. (2000) Narrative as Construct and Construction w: Narrative and the Cultural Construction of Illness and Healing, Ch. Mattingly, L. Garro (red.), Berkeley and Los Angeles, University of California Press.

Golonka-Legut J. (2012) Indywidualne doświadczenie życiowe obszarem uczenia się człowieka dorosłego w: Kultura jako przestrzeń edukacyjna. Współczesne obszary uczenia się osób dorosłych, W. Jakubowski (red.), Kraków, Oficyna Wydawnicza „Impuls", s. 45-62.

Hawkins A. (1999) Pathography: patient narratives of illness, "Culture and Medicine", no 171 , s. 127-129.

Jurgiel-Aleksander A. (2015) Jaka edukacja i dla kogo? Biografie edukacyjne dorosłych i ich społeczny wymiar, „Rocznik Andragogiczny”, s. 79-100. 
Karpiak I. (2000) Writing Our Life: Adult Learning and Teaching Through Autobiography, "Canadian Journal of University Continuing Education", vol. 26, no 1, s. 31-50.

Knowles M. (1980) The Modern Practice of Adult Education. From Pedagogy to Andragogy, wyd. 2, Englewood Cliffs: Prentice Hall Regents/Cambridge.

Mazurek E. (2015) Illness Narratives - Between Personal Experience, Medical Discourse, and Cultural Practice, "Croatian Review of Rehabilitation Research", vol. 51, no 1 , s. 48-58.

Mazurek E. (2017) Biograficzne uczenie się i narracyjne uczenie się - ramy teoretyczne, „Edukacja Dorosłych”, nr 1(76), s. 51-65.

Maruszewski T. (2005) Pamięć autobiograficzna, Gdańsk, Gdańskie Wydawnictwo Psychologiczne.

Nowak-Dziemianowicz M. (2014) Narracja w pedagogice - znaczenie, badania, interpretacje , „Kultura i Edukacja”, nr 2 (102), s. 7-44.

Nowak-Dziemianowicz M. (2016) Walka o uznanie w narracjach. Jednostka i wspólnota w procesie poszukiwania tożsamości, Wrocław, Wydawnictwo Naukowe DSW.

Polkinghorne D. E. (1988) Narrative Knowing and the Human Sciences, SUNY Press.

Ricoeur P. (1992) Filozofia osoby, tłum. M. Frankiewicz, Kraków, Wydawnictwo Naukowe Papieskiej Akademii Teologicznej.

Riessman C. K. (2002) Illness Narratives: Positioned Identities, Invited annual lecture, Health Communication Research Centre, Cardiff University, Wales.

Riessman C. K. (2005) Narrative Analysis w: Narrative, Memory \& Everyday Life, N. Kelly, Ch. Horrocks, K. Milnes, B. Roberts, D. Robinson (red.), Huddersfield, University of Huddersfield, s. 1-7.

Riessman C. K. (2008) Narrative Methods for the Human Sciences, Thousand Oaks, California: Sage.

Rosenthal G. (1993) Reconstruction of Life Stories: principles of selection in generating stories for narrative biographical interviews, "The Narrative Study of Lives", no 1 (1), s. 59-91.

Rosenthal G. (2003) The Healing Effects of Storytelling: On the Conditions of Curative Storytelling in the Context of Research and Counseling, "Qualitative Inquiry", vol. 9, no 6, s. 915-933.

Rossiter M. (2002) Narrative and Stories in Adult Teaching and Learning, „ERIC Digest", No. 241. 
Skibińska E. (2009) Dydaktyka biograficzna: nowy obszar poznawczy andragogiki czy nowa utopia?, „Teraźniejszość - Człowiek - Edukacja”, nr 2 (46), s. 51-70.

Tedder M., Biesta G. (2009) Uczenie się bez nauczania? Potencjał i ograniczenia biograficznego uczenia się dorosłych, „Teraźniejszość - Człowiek - Edukacja”, nr 2 (46), s. 19-35.

Tembeck T. (2009) Performative Autopathographies: Self-Representations of Physical Illness in Contemporary Art, Montreal, McGill University.

Trzebiński J. (2001) Narracja jako sposób rozumienia świata w: Praktyki opowiadania, B. Owczarek, Z. Mitosek, W. Grajewski (red.), Kraków, Wydawnictwo Universitas, s. 87-126.

Urbaniak-Zając D. (2011) Biograficzna perspektywa badawcza w: Biografia i badanie biografii, t. 1, Uczenie się z (własnej) biografii, E. Dubas, W. Świtalski (red.), Łódź, Wydawnictwo Uniwersytetu Łódzkiego, s. 11-27.

van Langenhove L., Hareé R. (1993) Positioning and Autobiography. Telling Your Life w: Discourse and Lifespan Identity, N. Coupland, J. F. Nussbaum (red.), London, Sage Publications, s. 81-99. 